\title{
Revisiting a family approach in youth ministry
}

Author:

Anita Cloete $^{1}$

Affiliation:

${ }^{1}$ Department Practical Theology and Missiology, University of Stellenbosch, South Africa

Corresponding author: Anita Cloete, acloete@sun.ac.za

Dates:

Received: 08 Jan. 2016 Accepted: 20 May 2016 Published: 19 Aug. 2016

How to cite this article: Cloete, A., 2016, 'Revisiting a family approach in youth ministry', In die Skriflig 50(1), a2078. http://dx.doi. org/10.4102/ids.v50i1.2078

\section{Copyright:}

(c) 2016. The Authors. Licensee: AOSIS. This work is licensed under the Creative Commons Attribution License.
Read online:
The primary aim of this article is to reflect on the 'family' of a family approach in youth ministry. The overall aim of the article is to confirm the importance of family as social and, specifically, a religious institution. Therefore, a family approach in youth ministry is of utmost importance, but it is argued that it is more feasible if the responsibility is taken up to continuously reflect on being a family in contemporary society. That implies that reflection on family is as much a cultural task as a theological task. Therefore, an interdisciplinary reflection is valued as cultural, is multifaceted and an ever chancing phenomenon. One of the outstanding characteristic of families today is diversity. Diversity, with regards to family, is mostly related to the structure of family and attention has therefore been paid to it in a section of this article. It is argued that diversity should not be perceived as negative, because, despite of the diverse structure of family, constructive relationships is proposed as the binding and constitutive factor in being a family. The focus on relatedness moves beyond blood ties to relatedness and solidarity as fundamental for our humanness. Thatcher (2007:6) differentiates between a structural and relational approach to family. A relational approach is opted here with the emphasis on the quality of the dimension of the relationships. These relationships are also understood to be grounded in theological sources such as the Person of God and the church.

\section{Introduction}

The central focus of this article is the 'family' of a family approach in youth ministry. A short explanation of a family approach in youth ministry is followed by a discussion on the complexities with regard to the reality of being a family. It is argued that a continuous reconceptualization of what is meant by a family is necessary. The interplay between 'context' and 'family' as well as the connection between 'marriage' and 'family' is discussed. The theological perspective on family includes a biblical perspective as well as a broader and more inclusive theological understanding of family. The article does not argue against a family approach, but emphasises the importance thereof. The need is identified to pay attention to the complexity and diversity that accompanies family and the implications thereof for a family approach in youth ministry. Furthermore, the importance of a theological informed family approach is advocated, for it anchors this approach in the redemptive grace of God in his dealings with people. The first section focuses on a description of families, mainly from a sociological and family studies perspective, while the last section pays attention to a theological perspective on family and the implications thereof for implementing a family approach in youth ministry. The author engages as a practical theologian in the interdisciplinary reflection on family and uses the insights from other disciplines to understand what is going on in the empirical reality with family and attempt to respond to that from a theological perspective. The theological perspective on family is informed by a Christian theological and relational approach. The local South African context is of importance and therefore the statistics that are used are specifically from family life in South Africa. I use the terms family approach and family ministry interchangeable as I understand both to have the same overarching aim, namely passing on the faith between different generations. Special attention is given to youth who come into this world through families and are therefore to great extend very dependent on family as a space of learning about life, how to live your life and the embodiment of forgiveness and love. Youth is here understood as more than a specific age that could be associated with development theory. It is also understood as a cultural construct that did not exist before the industrial revolution, but was created especially through industrialisation and institutionalised through institutions such as schools (Cloete 2012:1). Such a perception also implies that the understanding of youth should be more fluid as culture is not static.

\section{A family approach in youth ministry}

A family approach in youth ministry could be viewed as a response to the specialised and age specific youth ministry that, in most cases, develops into a separate ministry - segregated and 
isolated from the congregational ministry (De Vries 1994:41). Youth workers, however, soon realised that working with youth in isolation from particularly the parents, is fatal. Therefore, a family approach has been suggested to address the gap between youths and adults. In a family approach to youth ministry, parents are seen as indispensable partners in ministry, for youth workers will never replace the family context. The family is seen as the primary hermeneutical space where children come to an understanding of themselves, others, the world and God (Nel 2000:19). Youth programs can therefore not compete with the formative power of the parents at home (De Vries 1994:64). De Vries (1994:85) describes youth ministry without the involvement of the family as 'driving a car without an engine'. Youth ministry and family structures are thus understood as interdependent, for youth ministry builds on what is taught and modelled in the family home and should therefore be practised in co-operation with parents or care givers. The value of this approach is the acknowledgment of the vital role of family life in the holistic development of young people. These sentiments are echoed by Strong (2014:1) when she postulates that the crisis in youth ministry could be addressed by embracing a family approach in youth ministry. It seems that Strong (2014:2) favours the nuclear family consisting of a father and mother who are married and have children. She refers to that as the model that God instituted and that should guide our conceptual understanding of family. Summarily Knoetze (2015:1) argues for a family and youth ministry that is embedded in the missio Dei from an African perspective. He focuses especially on the contextual nature of such an approach. Although he makes references to the diversities of African families and youth, he does not elaborate or engage with that notion at all.

Although there seems to be much support for this approach, there is little discussion on the complexities of family life today and a lack of engagement with the diversity that is part and parcel of family life. In this article it is argued that in order to implement and facilitate a family approach in youth ministry, it is necessary to engage with the complexity and diversity of a family and the lived reality of being a 'family'. Therefore, the first part of this article focuses on the inherent diversity of a family by discussing the concept of family as well as the tendency to idealise the nuclear family. The assumption that marriage is equal to be a family is also engaged with. The complex nature of families is further accentuated by the discussion on the paradox of family and the interrelatedness between context and family. Without a revisiting of what is meant with the 'family of a family approach, youth ministry could exclude youth whom we intend to reach by this very approach. In the following section certain assumptions and paradoxes with regard to a family as well as the contextual nature thereof, is highlighted.

\section{Diversity as integral part of being family}

The concept family is recognised in different disciplines, for example sociology, psychology, economics, law and theology. The book Family Transformed: Religion, Values and Society in
American Life by Tipton and Witte (2005), illustrates the richness of this interdisciplinary concern for family by compiling thought provoking reflections on chancing family life from a variety of disciplines like anthropology, law, ethics and sociology to name a few. Therefore, it is safe to argue that family as a social institution is a well-known and used concept across disciplines and cultures. Although that is the case, it does not imply that all disciplines' views on the conceptual understanding and functioning of families are the same. In order to get some conceptual understanding of family, questions such as the following are implied: What constitutes a family? What does a family look like? What is experienced as a family? The questions asked in defining a family, point to the diversity that can be expected in the answers. According to Mvududu and McFadden (2001:17), diversity accepts difference as part of social reality, allows a wider understanding of a family and could keep us from speaking and understanding a family as a timeless entity. Although that is the case, there is still the myth that family life in the past has been better and that leads to the romanticising of the family of the past. In this process we are selective in what we remember about a family and we do not take into account the changes that have occurred over the past decades. In fact, this glorified idea of an historical family never existed as such 'nostalgic images of the 'traditional' families mask the inevitable dilemmas that accompany family life'. According to family historians there has never been a golden age of the family as it has always been afflicted with internal and external conflict (Zinn \& Eitzen 2005:10-11).

A family is definitely not a static or one-dimensional reality, although there has been the need and attempt to generalise and universalise what it means. In order to account for the diversity with regard to a family, some researchers prefer to refer to 'families' or 'doing family' instead of 'the family' (McKie \& Callan 2012:47). The reason for the tendency to generalise with regard to what a family means, could be because of the culturally embedded images of a family as well as our own experiences of a family. It is thus almost impossible to think objectively about a family and family life (Zinn \& Eitzen 2005:3). Despite of the challenge to think and speak objectively about a family, our conceptual understanding of it could be further informed by certain assumptions about what constitutes a family and what it should look like.

\section{Nuclear family as ideal family}

For many the nuclear family, where people are married and have children, is the ideal form of being a family (Mvududu \& McFadden 2001:11). Researchers in family studies describe this tendency as the ideology of the family as it has been powerful in promoting the nuclear family especially in industrial and post-industrial societies (McKie \& Callan 2012:47). Bernardes (1985:275) expresses his concerns that an 'ideal family' becomes standardised against which the virtues or deficiencies of other families are assessed. The implications of the understanding of a family as a nuclear family are multiple. Marriage between heterosexual partners is often 
viewed as the entry point of being a family, where people care for each other and fulfil certain responsibilities towards each other (Zinn \& Eitzen 2005:7-8). McKie and Callan (2012:47) confirms this idealistic view of a family when they state 'Despite all the evidence of inequalities, abuses and tension, family life is generally viewed as a positive goal, something we all want to be part of.' Conflict theories, as part of family studies, focus on power inequalities in families and bring into view the family as an oppressive system, which is pointing to the negative potential of families (McCarthy \& Edwards 2012:34).

Other assumptions of this positive view of family are that parents have the skills and material means to care for their families. This idealistic view of family does not always correlate with the harsh reality that these nuclear families often become spaces of neglect and abuse. Certain roles are often assumed, which are sometimes confined to gender roles, for example women as the nurturers and men as the bread winners. Again, this is not how most societies operate today where same sex marriages occur, and where women are working alongside men and in some instances are the only or primary breadwinners. Many others do not fit the traditional criteria of family, because they are married, but do not have children and others are single with or without children.

Some years ago, Sell (1995) already described the family as a changing and troubled unit. A report of the South African Institute for Race Relations by Holborn and Eddy (2011) gives a significant overview of the realities of family life in South Africa and how it influences the youth of the country. This report indicates that the 'typical child' in South Africa is raised by a mother in a single-parent household, or by unemployed parents or adults. The HIV pandemic and violence are some of contributing factors towards the high counts of child-headed households in South Africa. The risks of children being left alone to care for themselves are severe and include, for example to miss out on school, being unprotected in many ways, being prone to anxiety and depression, and being exposed to HIV infection (Holborn \& Eddy 2011:2). An increase in absent fathers and poverty is also indicated as one of the worrying trends.

These trends are often linked to dysfunctional family life (Holborn \& Eddy 2011:6). With these realities present in the South African context, the report concludes that growing up in a stable family is an impossible dream for many young people in South Africa. It is evident from this report on family life in South Africa that the nuclear family is not the family context for most children and youths. Even within nuclear families where both parents are present, the contact of parents with their children is more limited than in the past. In most cases both parents work and youths are more exposed to the media, which became one of their important resources of information. Zinn and Eitzen (2005:1) describe the family today as follows: 'More diverse, more likely to be formed outside marriage, includes a complex array of domestic arrangements and are easily fractured.' These empirical realities beg for a revisiting and redefining of the conceptual understanding of a family.

\section{Marriage and family}

With regard to the view that marriage is part and parcel of a family, Wilson (2002) is of the opinion that:

\begin{abstract}
... the purpose of marriage was to secure the family, not to redefine what constitutes a family. The family is a more fundamental social reality than a marriage, and pretending that anything we call a marriage can create a family is misleading. (p. 24)
\end{abstract}

Dana Garland (1996:1100) extends this view when she states 'Family is more than marital status'. Earlier marriage was viewed as an economic unit where the husband is the provider for the rest of the family; today the focus is more on companionship. Other forms of family start to become common due to cohabitation, high divorce rates, which lead to single-parent families, and out-of wedlock births (Browning 2003:8-9). Marriage has fulfilled a role as rite of passage into adulthood, but the timing, reason for marriage and expectation of marriage has also changed. Some young adults delay marriage till later in their life, which means they are dependent on their parents for a longer period. There is also a shift from seeing marriage as a public and religious institution to viewing it as a private, intimate partnership between two consenting adults with little or no interference of state or religion needed (Tipton \& Witte 2005:176). Gonzalez (2011) agrees that:

the choice of whether and whom to marry has increasingly been seen as a personal, individual decision and it is no longer important to the functioning of the industrial state that all persons marry, unless they wish the state to adjudicate property or child custody rights. (p. 7)

Although marriage could be viewed as an important social institution, it seems that the idea of marriage being part of being family and even the reasons for getting married, have changed and should be taken note of when we talk about family and a family approach in youth ministry.

\section{The paradox of family}

Family could be understood as a private and public reality at the same time. The public reality of family is mostly associated with the positive and idealised idea of family as described before. This public face makes us think that we know exactly what family means, that it is familiar and known. On the other hand, the private reality of family refers to the mysterious side, which is referred to as 'the myths, secrets, and information-processing rules that determine what can be said, more important, what cannot be said' (Zinn \& Eitzen 2005:3). It is expected of a family to keep us safe from society, but at the same time prepare us for society. So could the family be expected to be a safe emotional and physical space, but because of the emotionally intensive nature of close relationships like families, the very closeness could lead to conflict and vulnerability not experienced in emotionally less intensive relationships (Zinn \& Eitzen 2005:10-19). This means that a family always has to deal with almost 
unexpected ambiguity. This paradoxical nature of family life needs to be taken into consideration when we conceptualise on what a family could mean as well as the function of family in society. To assume that all people that live together take care of each other is not true. The close and intimate relationships that characterised families unfortunately often become the breeding ground for misuse and abuse. It could, however, at the same time create space for growth where love and acceptance is experienced. For a more realistic and balance view of family both possibilities should be kept in mind when we argue and proposes a family approach in youth ministry.

\section{Context and family}

Families are sometimes referred to as small building blocks of the larger society (McKie \& Callan 2012:111). Although that may be a valid view of a family, a family is not merely a cultural symbol and social institution. A family is influenced by the social reality as much as the family influences the social reality. This could be described as reciprocity in the relationship between a family and social factors. A family as social institution therefore reflects the economic, political, cultural and religious state of a society at a given time, but can also influence these. Therefore, the conceptual understanding of what constitutes a family should be revisited regularly, as these social factors influencing it, change all the time (McCarthy \& Edwards 2012:62). In order to adapt to changing circumstances families rearrange themselves all the time. In this process of adjusting, adapting and reorganising, a family influences society in many ways. For instance, most families adjust to the market economy with both parents working, which lead to the children being raised by teachers, social workers and especially media. This could potentially leave the parents with little or no voice or authority with regard to their children (Zinn \& Eitzen 2005:12). In this section the social embeddedness of family as well as the complex and diverse nature thereof, are highlighted. The following section pays attention to a theological perspective on family.

\section{Theological perspective on family}

In Christian theology the Bible is the normative source that informs our theological perspectives on a family. Assumptions when reflecting on a family from a theological perspective include that the Bible portrays the ideal type (structure) and kind (how to be family) of a family. With regard to the structure, the nuclear family, where heterosexual couples are married and have children, are often seen as biblical and therefore the ideal family. According to Graham (1998:162), another strategy to view family life, which is almost the opposite to the view of the nuclear family with heterosexual partners with children as the ideal, is that this traditional understanding of family is out-dated and even dangerous, and should be challenged and modified. Both these assumptions are problematic in many ways. Thatcher (2007:25) notes that there are two major challenges when engaging with the Bible on families, namely the discontinuities between the biblical times and the present as well as the plurality of voices from the biblical witness. It is therefore safe to argue that there is no blueprint for family life in the Bible. It is also dangerous to disregard the nuclear family between heterosexuals as out-dated. The nuclear family definitely has a place and value in society today. These opposite positions, in my view, confirm the lack and even ability to engage with the diversity that accompanies family life.

Portraits of family in the Old Testament, according to Dearman (1998:119-120), include a broad range of dysfunction and intrigue as well as the fragile nature of the community found in a family inclined to human sinfulness. At the same time the mysterious ways of God to bless them in spite of human fallibility are also evident. Furthermore, the family in the Old Testament was community orientated, contrary to the increasing individualistic nature of a family today. It is also important to note that the Bible is patriarchal and a family could be seen as one of the contexts which are primarily patriarchal in the Bible. Patriarchy is viewed as painful and hurtful today, but a family cannot be seen or understood apart from this, especially in the Old Testament. Barton (1998:130) warns us to be careful in asking what the Bible says about a family, because in our eagerness to hear what the Bible says, we fail to consider how the Bible speaks and how we hear or listen to it. Christians tend to stretch the biblical passages on a family across centuries to function as scripture on a family today, while biblical scholars try to stretch the gap between ancient documents and life. Insights from both these perspectives are valuable, but need to be in conversation all the time, as both views have limitations, which Barton (1998:131) describes as being crippled by positivism of text and history. It is, however, not possible to reproduce a family of the Bible today, because these two worlds are just too far apart. As Dearman (1998) postulates:

the modern Western term 'family' does not have an exact equivalent in the Old Testament, and the reason is that the two societies in question have different ways of defining kinship and social identity. (p. 117)

In light of these factors, Purvis (1998:148) is of the opinion that the Bible is a dangerous book both for what it says directly and for the social practices that it has established and still perpetuates in our culture'. It is thus not helpful and even problematic to look to the Bible for models for family today (Purvis 1998:151). Having referred to the complexity of using the Bible as normative on how family structures should look and how families should live today, it is important to indicate it does not mean that the Bible is of no use or has nothing to say on family life. The question should rather be what responsible ways there are to engage with the Bible on contemporary questions on a family? Graham (1998:163) suggests that we 'develop divine and coherent and viable central theological norms for evaluating diverse forms of family today'. Purvis (1998:152) is of the opinion that if we approach the Bible as a book that is primarily about God and secondary about humans it will be of much more help to us today. Using thematic approaches like a family to engage with the Bible is therefore just too problematic to characterise 
the Bible as a whole. The centrality of God in reading the Bible is therefore an important condition also with regard to a family. The orientation towards God, when engaging with the Biblical text, could potentially rephrase and even change our questions (Purvis 1998:155). Our question could then start with 'How did God deal with families in the Bible?' instead of 'What does the Bible tell us on family life today?' or 'What does family as a context of relationships teach us about God and his relationship with mankind?' The Bible tells us about a graceful and forgiving God in his dealings with people despite their sinfulness and the structure they belong to. We learn about a God that always takes the initiative in order to have a relationship with his creation to the point that he sent his Son to become human to die on the cross and to rise again to restore all broken relationships. It therefore seems helpful to see a family not as a mere structure, but as a context where grace, love and forgiveness are present. In the words of Purvis (1998:156) 'The Bible is most useful when it pushes us beyond the particularities of our family units, to consider the well- being of all persons.' The family metaphor is present throughout Scripture as an illustration of the necessity of people having a relationship with God and each other. In the New Testament all believers are called the children of God, which implies those having a relationship with God through Jesus and with others across generational lines. Life-shaping relationship with God and each other are therefore core elements of being family.

Strommen and Hardel (2000:15) corroborates when they postulate that the focus of the Bible is not on the family as collective unit, but on the relationship that exist between the children and adults in any configuration of family. In light of this biblical perspective of family Strommen and Hardel (2000:17) opt for a broad definition of family that includes parents, friends, mentors and relatives. Furthermore, they describe family as '... those people with whom we share our faith, values and purpose as they relate to a life of hope and love' (Strommen \& Hardel 2000:17). A second priority for being family is pointed as seeking the kingdom of God (Mt 6:33; 10:37-39). Being a family is therefore being together in service of the kingdom. We are connected with each other through the redemptive love of the King whom we are also called to serve together. This responsibility implies that we are prepared to move out of our theological comfort zones and willing to respond to socio-economic challenges and spiritual questions that the next generations are facing (Knoetze 2015:2). Family ministry therefore needs to be contextual and cultural sensitive as well as relevant. A family approach should be embedded within the broader community. That implies that it does not revolve around events and programmes offered at church only, but takes into consideration the needs of the broader community where families and youth are situated. Co-operation with other organisations in the specific community should therefore be an important goal. Family ministry often becomes institutionalised and limited to the church as institute without networking and partnering with relevant community organisations within the broader community that offer services to the same families.
Family ministry is not about saving the church through the youth, but rather the inclusion of youth in the mission of God on earth. The youth is therefore not the object of a family approach, but also the subject of youth ministry as part of the missio Dei (Knoetze 2015:5). In family ministry we do not do things to or for the youth, but it is rather a holy way of living towards God and each other (Knoetze 2015:2). Family ministry should therefore not only assume roles for adults (parents, care givers, mentors, etc.), but also for the youth as active participants in the ministry. Family ministry is therefore more about sharing what we believe, embodying what we believe together, but also seeking together (faith seeking understanding). In this regard listening to each other's questions, doubts and fears will be of importance in order to establish a trusting community that are open to a diversity of voices and opinions. Dialogue will thus be at the heart of a family approach in ministry. Family ministry is therefore people of different generations that journey together in service of the King, taking responsibility for each other. Putting differently, a family approach to youth ministry is as a result also characterised by intergenerational ministry. Seibel and Nel (2010:1) remind us about the calling of the church to perpetuate the faith tradition from one generation to the next and doing so with patient endurance. In this process all participants are receiving and making future tradition. The focus of a family approach is exactly that: to create space where different generations could learn about their faith, but also witness to each other about it in their own ways and subcultures.

\section{Conclusion and implications for a family approach in youth ministry}

If a family approach in youth ministry implies a certain structure or form such as the nuclear family, it will definitely lead to the exclusion of the youth we try to reach with this very approach. A family approach should rather be informed by an understanding of a family that is embedded within the reality of community life. Therefore, a family approach should not be a program that is primarily driven by the church with certain people, but should rather have a community focus that includes and respects the diverse forms of families. Amidst the diversity that characterised family life, relationships seem to be a key in constituting being a family. In that sense 'family could be understood as verb rather than a noun' (Anderson 2001:259). Thatcher (2007:5) refers to the use of family practices as an attempt to define being family. In light hereof I would suggest that a family approach in youth ministry should focus on relationships where young people discover and learn about life, themselves and God. The focus on constructive relationship could thus be viewed as one of the most important criteria for being a family and a family approach in youth ministry. Relationships and being a family seem to be two sides of the same coin. If relationship is a core element in being a family, I found it fit to view a family as a process rather than as a static arrangement. A family could be seen as a community of constructive relationships whereby all humans are nourished and cannot live without. In youth ministry the focus should therefore be on connecting youths 
with significant others with whom they could be in positive relationships and where they are nurtured and cared for. Dykstra (2005:97) emphasises the point that family is more than a certain arrangement, but are inclusive and not limited by stereotypes. The link between people makes them family. This link should be deeper than biological or sociological, but, according to Dykstra (2005:97-98), it is in promise-making between people. These promises should be embedded in God's promises to us and are consequently not hopeless when we do not keep our promises. Therefore, liturgies such as marriage and baptism should be make more of today, because it gives platforms for promise-making and points of reference of God's promises to us (Dykstra 2005:105-107). Bellah (2005:28) also advocates for institutions like marriages, although that may not be an obvious need or truth for modern people today. His motivation is that we define ourselves in relation to others and the fact that we may think that we could live without others is not necessarily true. Bellah's argument should, however, not be understood to mean that only married people should be regarded as family, but rather that social and sacred institutions like marriage could be of great value in sustaining what it means to be family. Bellah (2005:30) qualifies his understanding of marriage further by stating that marriage should not be viewed from a contractual perspective, but rather put solidarity central. Even more important is his opinion that marriage as institution should also be subjected to continuous reform (Bellah 2005:30).

The reality of brokenness and fragility in human relationships should be reckoned with, but even more the presence of God's grace and forgiveness in these fragile human relationships should be acknowledged. A family approach should bear witness to the fact that God's love for his creation makes it possible to overcome our shortcomings and sinfulness which are so often expressed through broken and destructive relationships in family life. The healing power of God's grace and forgiveness in human relationships help us to focus on what God has already done for us in order to take responsibility for each other, and be channels of this grace and forgiveness in our relationships. This view of a family helps us not to be desponded due to the challenges families face as the focus shifts to God's graceful dealings with people, despite and amidst their misery. A family has a strong eschatological dimension in that it points to what the Holy Spirit makes possible today in anticipation of a new reality yet to be revealed (Barton 1998:132). Although a family gives us a bodily presence with and responsibility towards each other, it always points to the incarnation of God coming to us in order to reveal his grace in Jesus Christ for all creation. A family approach is therefore more than just an educational program where people learn how to be family to each other, but it is primarily a context for Christian discipleship (Garland 1996:1100).

\section{Acknowledgements Competing interests}

The author declares that she has no financial or personal relationships which may have inappropriately influenced her in writing this article. I confirm this statement

\section{References}

Anderson, R.S., 2001, The shape of practical theology: Empowering ministry with theological praxis, InterVarsity Press, Westmont, IL.

Barton, S.C., 1998, 'Living as families in the light of the New Testament', Interpretation 52(2), 130-144. http://dx.doi.org/10.1177/002096430005200203

Bellah, R.N., 2005, 'Marriage in the matrix of habit and history', in S.M. Tipton \& J. Witte Jr. (eds.), Family transformed: Religion, values and society in American life, pp. 21-33, Georgetown University Press, Washington, DC.

Bernardes, J., 1985, 'Family ideology: Identification and exploration' Sociological Review 33(2), 275-297. http://dx.doi.org/10.1111/j.1467-954X.1985.tb00806.x

Browning, D.S., 2003, Marriage and modernization: How globalization threatens marriage and what to do about it, Eerdmans Publishing Company, Grand Rapids, MI.

Cloete, A., 2012, 'Youth culture, media and sexuality: What could faith communities contribute?' HTS Teologiese Studies/Theological Studies 68(2), Art. \#1118, 6 pages. http://dx.doi.org/10.4102

Dearman, J.A., 1998, 'The family in the Old Testament', Interpretation 52(2), 117-129. http://dx.doi.org/10.1177/002096430005200202

De Vries, M., 1994, Family -based youth ministry, Intervarsity Press, Westmont, IL.

Dykstra, C., 2005, Growing in the life of faith: Education and Christian practices, Westminster John Knox Press, Louisville, KY.

Garland, D.R., 1996, 'Families and congregations: What is family ministry?', Christian Century 13, 1100-1101.

Gonzalez, N.L., 2011, 'Matches made on earth', Humanist 71(1), 12-17.

Graham, L.K., 1998, 'Pastoral care of diverse families', Interpretation 52(2), 161-177. http://dx.doi.org/10.1177/002096430005200205

Holborn, L \& Eddy, G., 2011, First steps to healing the South African family, South African Institute of Race Relations, Johannesburg.

Knoetze, J., 2015, 'Perspectives on family and youth ministry embedded in the mission Dei - an African Perspectives', In die Skriflig 49(1), Art. \#1874, 9 pages. http:// dx.doi.org/10.4102/ids.v49i1.1874

McCarthy, J.R. \& Edwards, R., 2012, Key concepts in family studies, Sage Publications Ltd., London.

McKie, L \& Callan, S., 2012, Understanding families: A global introduction, Sage Publications Inc., Los Angeles, CA.

Mvududu, S. \& McFadden, P., 2001, Reconceptualizing the family in a changing Southern African environment, WLSA Regional Office, Harare.

$\mathrm{Nel}, \mathrm{M} ., 2000$, Youth ministry: An inclusive congregational approach, Kitskopie, Pretoria.

Purvis, S., 1998, 'A question of families', Interpretation 52(2), 145-160. http://dx.doi. org/10.1177/002096430005200204

Seibel, C.L. \& Nel, M., 2010, 'Generation X, Intergenerational justice and the renewa of the traditioning process', HTS Teologiese Studies/Theological Studies 66(2), Art. \#876, 7 pages. http://dx.doi.org/10.4102/hts.v66i2.876

Sell, C.M., 1995, Family ministry, Zondervan Publishing House, Grand Rapids, MI.

Strommen, M.P. \& Hardel, R.A., 2000, Passing on the faith: A radial new model for youth and family ministry, Mary's Press, Winona, MN

Strong, P., 2014, 'Effective youth ministry: Embracing a family approach,' In die Skriflig 48(1), Art. \#1715, 8 pages. http://dx.doi.org/10.4102/ids.v48i1.1715

Thatcher, A., 2007, Theology and families, Blackwell Publishing, Oxford.

Tipton, S.M. \& Witte, J. Jr. (eds.), 2005, Family transformed: Religion, values and society in American life, Georgetown University Press, Washington, DC.

Wilson, J., 2002, The marriage problem: How our culture has weakened families, HarperCollins, New York.

Zinn, M.B. \& Eitzen, D.S., 2005, Diversity in families, 7th edn., Allyn \& Bacon, Boston, 